\title{
Options to Increase Adoption of Lowland Rice - Legume Technologies in Morogoro, Tanzania
}

\author{
Albino Tenge ${ }^{1}$, George Ley ${ }^{2}$, Joseph Hella ${ }^{3}$, Magreth Kinyau ${ }^{2}$, Fina $\mathrm{Opio}^{4} \&$ Ivan Rwomushana ${ }^{4}$ \\ ${ }^{1}$ The University of Dodoma, Dodoma, Tanzania \\ ${ }^{2}$ Agricultural Research Institute Mlingano, Tanga, Tanzania \\ ${ }^{3}$ Sokoine University of Agriculture, Morogoro, Tanzania \\ ${ }^{4}$ ASARECA, Staple Crops Programme, Uganda \\ Correspondence: Albino Tenge, The University of Dodoma, P.O. Box 259, Dodoma, Tanzania
}

Received: April 4, 2013 Accepted: June 7, 2013 Online Published: June 24, 2013

doi:10.5539/jsd.v6n7p113

URL: http://dx.doi.org/10.5539/jsd.v6n7p113

\begin{abstract}
The main concern in agricultural research is to ensure that research products are adopted by farmers. However, the rate of adoption is low. Most research on adoption rates are post-ante. The values of such research can be added if factors for adoption are ex-ante identified and measures taken to increase adoption. This study was conducted in Morogoro, Tanzania to ex-ante identify socio-economic characteristics that influence adoption of Integrated Lowland Rice Legume Technologies (ILRLT). The ILRLT included integration of rice (SARO variety), legumes (cow pea) water management (irrigation, rainfed and majaruba bunds), tillage (conventional and minimum) and fertilizers (UREA, TSP and MOP). Data were collected through questionnaire interviews to 200 representative farmers and key informants. Descriptive statistics, Multi-Criteria Analysis and a two functions adoption model were used to assess the suitability of ILRLT and analyze the likelihood of farmers to adopt. Results indicated that important criteria for rice variety preference and hence adoption are high prices (7.8\%), good taste $(6.1 \%)$, early maturity $(4.8 \%)$, disease $(3.2 \%)$ and drought tolerance $(17.4 \%)$. ILRLT scored more $(26.40 \%)$ than farmer's $(17.97 \%)$ in fulfilling criteria for rice legume variety preferences. ILRLT have a chance of being adopted to the maximum rate of $89.7 \%$. Adoption is likely to be more with farmers who depend on irrigation than those who depend on rainfed rice farming.
\end{abstract}

Keywords: adoption, agricultural technologies, rice-legumes, Tanzania

\section{Introduction}

Adoption of research outputs to bring the desired impacts is among the main concern in research since its inception. However, the rate of adoption of most agricultural technologies is low and depends on the number of factors (Perret \& Stevens, 2003; Tenge, De Graaff, \& Hella, 2004; Knowler \& Bradshaw, 2006). These factors include personal characteristics such as age, education, marital status and others (Tenge et al., 2004). Resources availability and uses such as farm sizes, farm ownerships, and level of income have also been identified to influence the rate of adoption of agricultural technologies (De Graaff et al., 2008). In addition, to personal and resources characteristics there are institution factors that may influence adoption (Cramb, 2003; Kirway \& Lema, 2003; De graaff et al., 2008).

Despite of numerous studies on factors for adoption of agricultural technologies; socio-economic characteristics associated with adoption do vary with time and space (Stroup, Hildebrand, \& Francis, 1991; Degraaff et al., 2008). Hence circumstances in the target research areas, farmer's practices, resources availability and uses need to be thoroughly analyzed to minimize incidences of low adoption. In addition, most adoption studies have been done after the introduction of the technology (Tenge et al., 2004; De Graaff et al., 2008). The value of such studies can be added if factors for adoption of a certain technology can be identified before introduction, as it will be possible to take necessary measures and increase adoption.

Rice contributes significantly to food security in Eastern and Central Africa (ECA) (Ley et al., 2012). However, continues rice cropping is becoming a problem that threaten the sustainability of the lowland rice farming system due to creation of unfavorable soil conditions, underutilization of land and water resources depletion of nutrients and may cause build up of pests and diseases (Ley et al., 2012; Baltissen, Veldkamp, Nyaki, \& Schrader, 2002; 
Meertens, 2003). Researchers have developed integrated Lowland Rice - Legume Technologies (ILRLT) that will permit legumes establishment after rice and hence increase productivity of soil and water resources while enhancing sustainability through improvement of soil fertility (Ley et al., 2012). The success of this innovation however will depend on the extent to which the developed technologies are adopted by smallholder lowland rice farmers. The objective of the research whose results are presented in this paper was to investigate farmer's characteristics associated with the adoption of ILRLT, determine the suitability of ILRLTand the likelihood of adopting the rice-legume technologies.

\section{Methodology}

\subsection{Description of Research Sites}

This study was conducted in four villages namely Mkindo, Hembeti and Dihombo in Mvomero district and one village namely Tununguo (Mbarangwe) in Morogoro rural district. Both districts are in Morogoro region in Central East Tanzania. The region is located between $5^{\circ} 58^{\prime \prime}$ and $10^{\circ} 00^{\prime \prime}$ South, and $35^{\circ} 0^{\prime \prime}$ and $35^{\circ} 30^{\prime \prime}$ East (URT, 1997). Criteria for selection of these villages included dominance of small scale rice farmers, willingness of farmers to participate in the research activities, availability of land for research and accessibility. Mkindo, Hembeti and Dihombo villages within Mvomero districts are on flat plains at low altitude $(200-750 \mathrm{~m})$ developed on intermediate metamorphic rocks. The soils are loamy or clayey with low or moderate fertility status. The area has mainly one Dependable Growing Period (DGP) per year with duration of 3 - 4.5 months and a very short secondary DGP of $1-2$ months with unreliable onset dates (URT, 2008; Depaw, 1984). Tununguo village in Morogro rural district is on gently undulating to rolling plateaux at low altitude (200-500 m). The area is developed on Karroo sandstones and Neogene sediments. The soils are well drained (loamy) sands with low fertility status and poor to moderate moisture storing properties. The area has one DGP per year with duration of 3 - 4.5 months and unreliable on-set dates (URT, 2008; Depaw, 1984). Major economic activity on which about $80 \%$ of the population in both districts depend is agriculture, lowland rice being among the major crops (URT, 2008).

\subsection{Integrated Lowland Rice- Legume Technologies}

\subsubsection{Description of the Integrated Technologies}

The Integrated Lowland Rice- Legume Technologies whose potential to be adopted was analyzed in this study include integration of rice (SARO variety), legume (cow pea- vuli variety) water management (irrigation, rainfed and water bunds [majaruba]), tillage (conventional tillage, minimum tillage) and fertilizers (UREA, Triple Superphosphate [TSP] and Muriate of Potash [MOP]. In this integration rice is grown in irrigation and rain fed majaruba bunds with application of the three types of fertilizers. The legume is grown in rice fallow fields with minimum and conventional till practices. Details of the experiments are explained in Ley et al. (2012).

\subsubsection{Sustainability of the Integrated Lowland Rice Legume Technologies}

The ILRLT is expected to sustain the lowland rice farming system through improvement of the soil fertility from the legumes ability to fix nitrogen and additional of bio-mass to the soil (Das \& Ghosh, 2012). This will reduce the amount required from industrial fertilizers hence affordability and benefits to the farmers. The adverse effects of industrial fertilizers to the environment will also be minimized. Growing legumes after rice will break the cycles for common pests and diseases that attack rice hence minimizing the costs and environmental hazards from the use of pesticides. Integration of water bunds (Majaruba) will increase efficient in utilization of water resources and hence sustainability. Growing the legumes during dry season makes utilization of the land that would be left fallow, hence increases income and food security to the farmer. Legumes are also important sources of the protein hence can improve nutritional status of the lowland rice farmers.

Economic Analysis of the ILRLT by Kinyau et al. (2013) indicated higher Benefit Cost Ratio (BCR) of 2.9 when rice was rotated with legume compared to BCR of 1.4 when rice was planted without legumes. The analysis also showed that farmer's practices of growing rice without rotation with legume was unprofitable with an average yield of $1.8 \mathrm{t} / \mathrm{ha}$ compared to $4.1 \mathrm{t} / \mathrm{ha}$ with ILRLT. The analysis concluded that introduction of legumes is beneficial leading to increase in yield by more than $100 \%$. The yield increase was attributed to the ability of ILRLT to improve soil fertility, increase efficiency in utilization of water and land resources.

\subsection{Sampling Procedures}

The sampling frame for household survey consisted of lists of heads of households obtained from the respective village government offices. From the sampling frame, 50 head of households were randomly selected from each village making a total of 200 respondents. Key informants were purposeful selected and they included district 
agricultural officers, subject matter specialist, district agricultural extension officer, village agricultural extension officer and village leaders.

\subsection{Data Collection}

Data collection involved discussions with key informants and administering pre-designed questionnaire to the 200 representative households. Secondary data from scientific reports, maps and statistical abstracts were used as additional sources of data. The type of data that were collected included household's characteristics, resources availability and data on institution issues relating to building capacity of farmers in adoption of agricultural technologies. Other data type included farmer's perception and practices on soil and water management in lowland rice farming, yield levels and fertility improvement options. These characteristics were conceptualized to influence adoption based on scientific findings from other researchers (Semgalawe \& Folmer, 2000; De Graaff et al., 2008; Tenge et al., 2004).

\subsection{Data Analysis}

Data from the household interviews was coded and entered into spreadsheet using a Statistical Package for Social Sciences (SPSS) computer software (Norusis, 1990; Field, 2005). Qualitative data was analyzed using non-statistical methods such as content analysis, pair wise and matrix ranking technique which involved extracting the information and clustering it into themes and sub-themes and ranking according to priorities, weights or proportional of responses in a certain category (Bryman \& Cramer, 1990; Bryman, 2012; Kirway \& Lema, 2003). Quantitative data was analyzed using descriptive statistics of mean, frequency and percentages with the aim to establish the typical values of socio economic characteristics variables and to establish the proportion of farmers in each category (Devore \& Peck, 1993; Burns, 2000). Multi-Criteria Analysis (Tenge \& Strosnidjer, 2008; Bowerman, O'Connell \& Murphree, 2011) was used to determine the extent to which integrated rice legume technologies fulfilled farmer's criteria for adoption of technologies. Multi-Criteria Analysis involved identification of most important criteria and formulation of weights for each criterion based on farmers score for each. This was followed by aggregation and ranking. Scores for the integrated rice Legume Technologies was compared with the scores for farmers' practices. The additive weighting method was used to obtain the total weighted scores for each alternative. The alternative with the highest total weighted score was considered as the most preferred option (Tenge, 2005).

Likelihood to adopt the integrated lowland rice legume technologies was analyzed using a two functions adoption model (Kirway \& Lema, 2003; Sheikh, Mohamed, Bashir, \& Kashif., 2006) as summarized by Equation 1.

$$
M R A=\frac{[\mathrm{Cf}(\mathrm{i}, \mathrm{n}) * \mathrm{Gf}(\mathrm{i}, \mathrm{n}))]}{10000}
$$

Where:

$$
\begin{aligned}
& \text { MAR = Maximum adoption rate (\%) } \\
& \mathrm{Cf}(\mathrm{i}, \mathrm{n})=\text { Frequency of farmer categories }(\%) \\
& \mathrm{Gf}(\mathrm{i}, \mathrm{n})=\text { Frequency of Production goals }(\%)
\end{aligned}
$$

The adoption model assumed that technology adoption is a function of the relationship between farmer's category, production goals and production environment. Production environment variables in the study area were rain fed and irrigated rice production. Two categories of farmers were identified based on the sources of water for rice farming (irrigated, rainfed). Production goals were identified from objectives as specified in the reasons for farmer's preferences of rice varieties. These goals were food security (high yields, short duration), market (taste, high prices, market availability) and risk adverse (tolerance to drought, pests, disease and bird attacks). Production environments were irrigated and rainfed rice growing. Since the environment overlapped with category of farmers the model was reduced to two functions model.

\section{Results and Discussions}

\subsection{Farm Household Characteristics}

The type of household that reside and farm in the research areas are indicated in Tables 1. Based on the household characteristics and resource availability, households in the research areas can be distinguished in several ways as Male headed households (54.5\%) female headed (45.5\%) households, four age groups, and five education levels. These groups are likely to have different perceptions, awareness and abilities to implement the 
technologies developed. Care need to be taken so that there is no group that is marginalized. These characteristics are here under discussed.

\subsubsection{Sex of Head of Households}

Results in Table 1 show that representative sample had an average of about $54.5 \%$ male headed households and the rest were female.However, there was more (62.1\%) representation of female headed households in Mkindo than from other villages. The female headed households included single women (unmarried, divorced or widows) and married women whose husbands worked and lived in town.These results support other research findings (Tenge et al., 2004; Maro, 2010; Kashumba, 2010) that indicated dominance of male headed households in rural areas. This is according to traditional African values where the male is the head of household in most cases.

The sex of head of household may influence the adoption due to the fact that female have limited resources and access to the information about technologies due to traditional social barriers (Hella, 2002; Tenge et al., 2004). Women are also involved in many household activities than men. These results imply that promotion of agricultural technologies in rural areas should not target head of households only but other household members including female.

\subsubsection{Age}

The age has an influence on adoption of the technology as it determines planning horizon and production strategies based on experiences. Results (Table 1) indicate that on average about half (59.4\%) of farmers in the study villages are in age group of at most 45 years. These results indicate that there is still potential active labor force that could be engaged in farming and utilizing ILRLT. On the other end, the presence of very few old people may imply limited information on the indigenous knowledge and practices on soil and water management in lowland rice- legume farming systems and practices. There is a need to tap the relevant undocumented indigenous knowledge from the few aging people in the farming communities and integrate in the rice legume technologies.

Table 1. Household characteristics based on sex, age and education levels of respondents

\begin{tabular}{ccccccc}
\hline Variable & Description & \multicolumn{5}{c}{ Respondents by villages (\%) } \\
\cline { 3 - 7 } & & Mkindo & Hembeti & Dihombo & Tununguo & Total \\
& & $\mathrm{n}=50$ & $\mathrm{n}=50$ & $\mathrm{n}=50$ & $\mathrm{n}=50$ & $\mathrm{~N}=200$ \\
\hline Sex & Male & 37.9 & 59.4 & 48.3 & 72.5 & 54.5 \\
& Female & 62.1 & 40.6 & 51.7 & 27.5 & 45.5 \\
Age (yrs) & & & & & & \\
& $18-35$ & 34.5 & 37.5 & 31 & 41.2 & 36.5 \\
& $36-45$ & 24.1 & 9.4 & 34.5 & 23.5 & 22.9 \\
& $46-55$ & 25.9 & 28.1 & 27.6 & 13.7 & 22.9 \\
& $56-60$ & 5.2 & 3.1 & - & 7.8 & 4.7 \\
& $>60$ & 10.3 & 21.9 & 6.9 & 13.7 & 12.9 \\
Education Level & & & & & & \\
& Non-formal & 2.0 & 9.4 & 8.3 & 2.0 & 4.7 \\
& Primary & 83.0 & 84.4 & 88.2 & 92.2 & 90.0 \\
& Secondary & 3.0 & 6.3 & 3.4 & 3.9 & 4.1 \\
& College & 12 & - & - & 2.0 & 0.6 \\
\hline
\end{tabular}

The results from this study slightly differ from other findings that indicate absence of productive labor force in rural areas due to rural-urban migration particularly for youth seeking off-farm employment in towns (Tenge, De Graaff \& Hella, 2005; Maro, 2010; Kashumba, 2010). Presence of water for irrigation and availability of better markets for the rice produced particularly in Mvomero study villages can explain the observation. The results 
suggest that if risks to agriculture are reduced with assurance of better markets, agriculture can attract youth and make them remain in rural areas.

\subsubsection{Education Level}

Education level has implication on the awareness of several issues and the planning horizon. Educated households are expected to be aware of many issues related to agricultural technologies also to have a longer planning horizon. Results on education levels of the respondents (Table 1) indicate that majority (88-93\%) of the respondents had attained primary school education and few (2-9\%) had no formal education. The proportional of households with Secondary School education was very low (3-6\%). Small proportional of secondary school and college leavers who stay in the villages may imply that educated youths have little interest in agriculture or the village conditions are not conducive for them to stay. These different levels of education have implications on the design of communication products and means of communicating ILRLT.

\subsection{Rice Farming Practices}

\subsubsection{Types of Rice Farming}

Results on the type of rice farming in the study villages show that majority (67-76\%) of farmers in Mvomero (Mkindo, Hembeti and Dihombo villages) district grow irrigated rice (Table 2). The situation is different in Morogoro rural district (Tununguo) where only $4 \%$ of the respondents irrigated their rice fields. This is due to the presence of the irrigation scheme in the study villages in Mvomero district. The results indicate that in all villages almost all farmers (95-97\%) grow rainfed rice. Few farmers in Dihombo, Mkindo and Tununguo supplement the rainfed rice with irrigation during the period of drought. The results in Table 2 further reveal that few farmers were already trying to grow second crops after the rice. However, field observations and discussions with farmers indicated inadequate knowledge on the practices as many farmers were growing rice, vegetables or maize as second crop after rice harvest.

Table 2. Type of rice farming

\begin{tabular}{|c|c|c|c|c|c|}
\hline \multirow[t]{3}{*}{ Type of rice farming } & \multicolumn{5}{|c|}{ Respondents (\%) } \\
\hline & Mkindo & Hembeti & Dihombo & Tununguo & Total \\
\hline & $\mathrm{n}=50$ & $\mathrm{n}=50$ & $\mathrm{n}=50$ & $\mathrm{n}=50$ & $\mathrm{~N}=200$ \\
\hline Irrigated & 66.7 & 68.8 & 75.9 & 4.0 & 57.7 \\
\hline Supplementary irrigation & 1.8 & - & 24.1 & 2 & 5.4 \\
\hline Rain fed & 94.7 & 96.9 & 96.6 & 96.0 & 95.8 \\
\hline Growing $2^{\text {nd }}$ crop after irrigated rice & 27.8 & 40.0 & 42.9 & 9.1 & 30.4 \\
\hline Growing $2^{\text {nd }}$ crop after rain fed rice & 7.4 & 17.2 & - & 7.5 & 9.5 \\
\hline
\end{tabular}

This rotational is not technically advised as vegetables and maize do not have ability to fertilize the soil after the rice but increases nutrient depletion and hence the threat to the sustainability of the lowland rice farming system in the area. These results imply that the rice legume technologies complement to farmer's efforts to grow second crops after rice. Hence, increase the likeliness of adoption. According to De Graaff et al. (2008), farmers are likely to adopt technologies if relevant to their needs and environment.

Farmers in the study villages grow both local and improved rice varieties (Figure 1). Main local varieties are Super, Mbawambili, Rangimbili and Shingo yamwali. Improved variety is SARO which is grown mainly in Mvomero district villages (Mkindo, Hembeti and Dihombo) because of the presence of water for irrigation. With exception of super, all other local varieties are grown under rain fed conditions.

Results in Figure 1 show that among the local varieties grown under rain fed conditions, Supper is mainly grown in Mkindo and Tununguo villages by $74-76 \%$ farmers while Mbawambili is mainly grown in Dihombo and Hembeti villages by $72-90 \%$ farmers. However, yield levels mentioned by farmers during interviews are generally low especially for the local varieties. 


\subsubsection{Rice Varieties and Yield Levels}

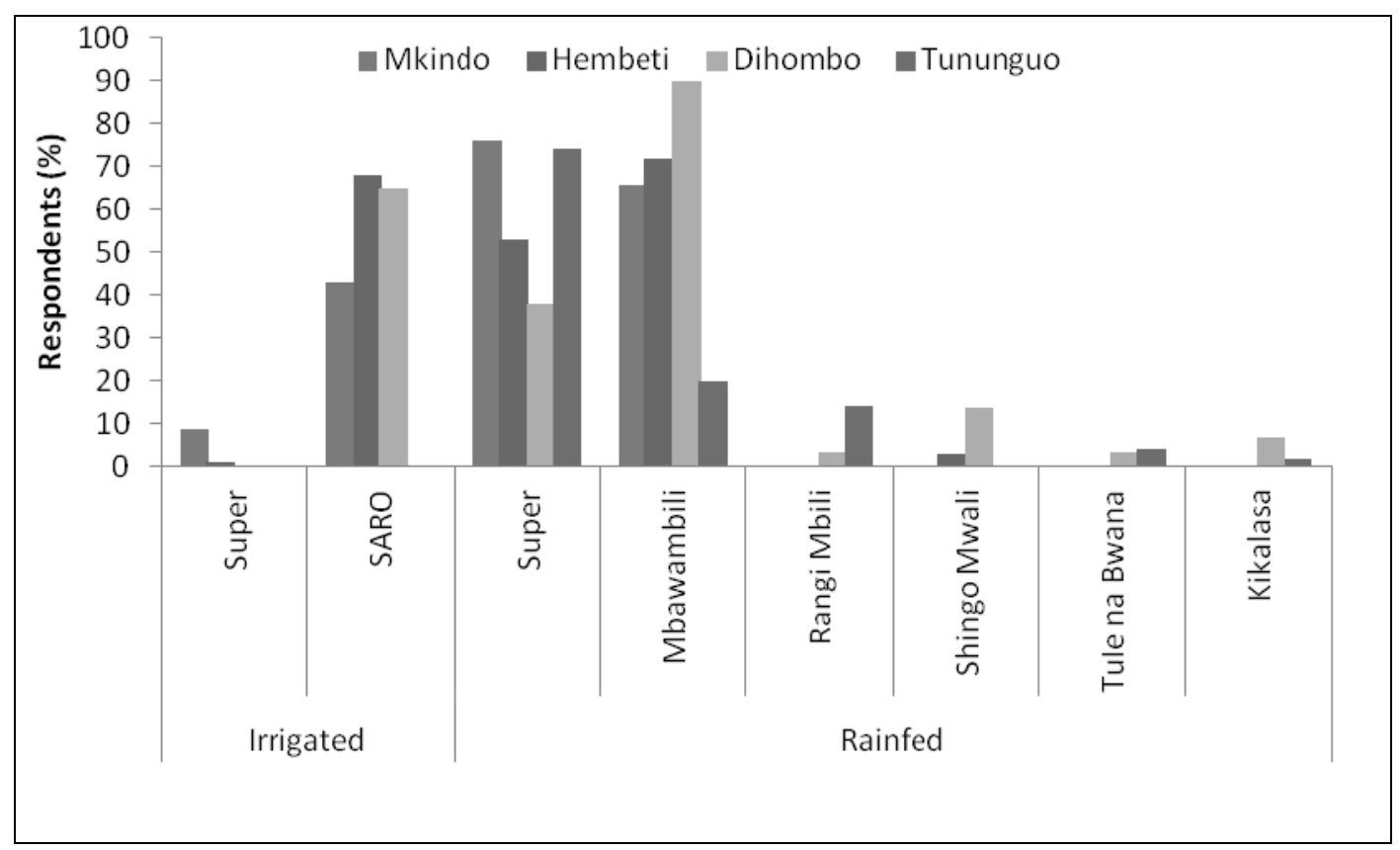

Figure 1. Irrigated and rain fed rice varieties in the study villages

\subsection{Adoption of Integrated Lowland Rice-Legume Technologies}

\subsubsection{Farmer's Criteria for Rice and Legume Variety Preference}

Farmers explained the reasons why they keep growing local varieties using traditional practices despite the low yields.

Results in Figure 2 indicate criteria farmers use to select rice variety. The results indicate that most farmers prefer local varieties because of their ability to tolerate drought conditions, market availability and good prices. The improved variety is mainly preferred because of its high yielding and market availability. These results indicate that farmers have multiple objectives and don't consider only one criterion. Considerations of these preference criteria when promoting ILRLT is likely to increase adoption. These results are similar to findings by Hella (2002) who observed the multi-objective nature of smallholder farmers, implying that technologies addressing only a single problem may have limited adoption by smallholder farmers. 


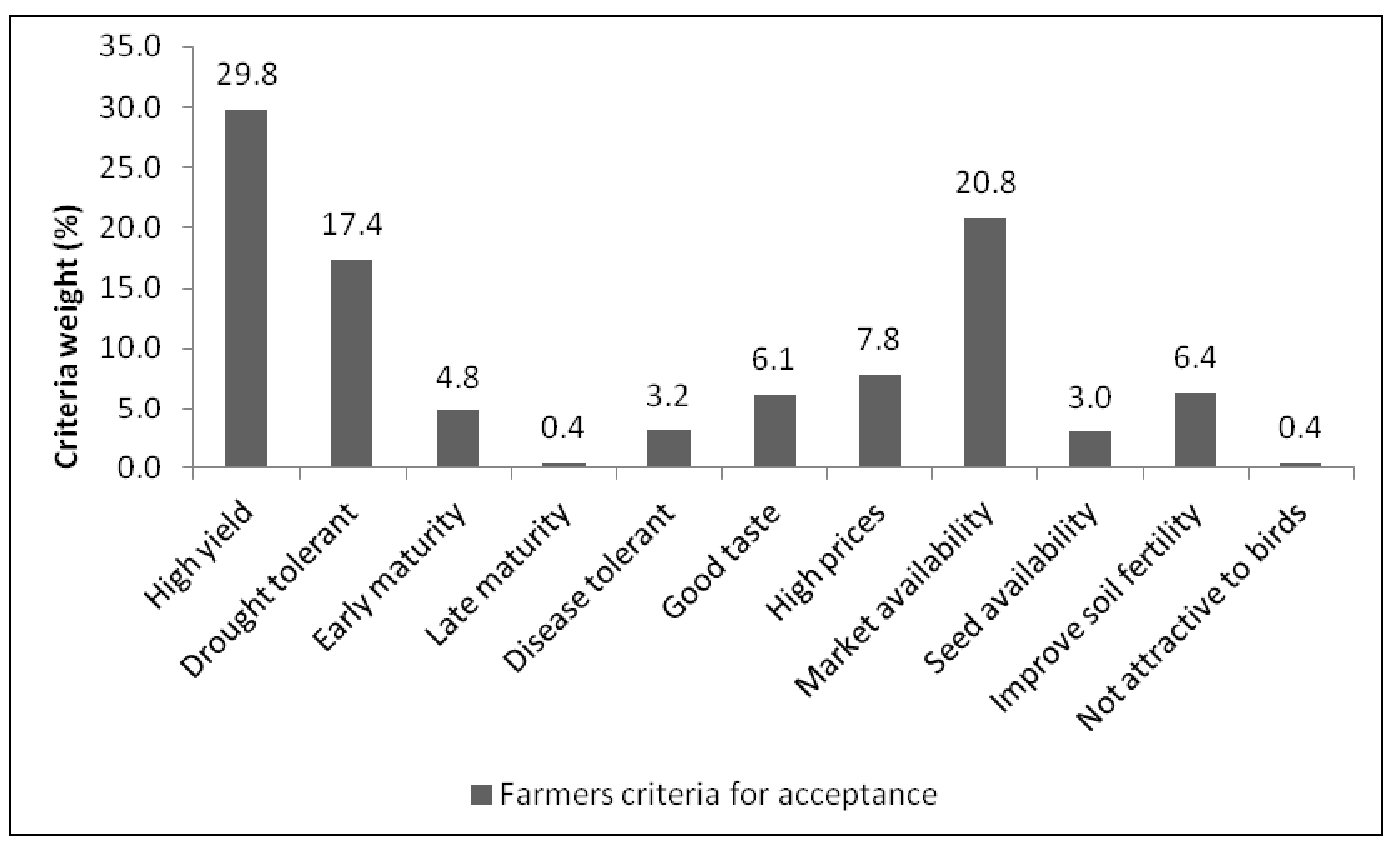

Figure 2. Acceptance of lowland rice legume technologies

\subsubsection{Effectiveness of Integrated Lowland Rice Legume Technologies to Fulfil Farmer' Criteria}

Multi Criteria Analysis results (Table 3) indicate that Integrated Lowland Rice Legume Technologies (ILRLT) is more superior to the conventional (farmer's practices) in fulfilling farmer's criteria, hence more suitable and more likely to be adopted.

Table 3. Effectiveness of Integrated Lowland Rice Legume Technologies to fulfil farmer's criteria

\begin{tabular}{|c|c|c|c|c|c|}
\hline \multirow[t]{2}{*}{ Criteria } & \multicolumn{2}{|c|}{$\begin{array}{l}\text { Scores }(\%) \\
\text { (S) }\end{array}$} & \multirow[t]{2}{*}{ Criteria weight $(\mathrm{Wt})$} & \multicolumn{2}{|c|}{$\begin{array}{c}\text { Weighted } \\
\text { Scores }\left(\mathrm{S}^{*} \mathrm{Wt}\right)\end{array}$} \\
\hline & ILRLT** & $\mathrm{CONV}^{*}$ & & ILRLT** & CONV* \\
\hline High yield & 60 & 16 & 0.30 & 17.90 & 4.80 \\
\hline Drought tolerant & 4.6 & 32.8 & 0.17 & 0.78 & 5.58 \\
\hline Early maturity & 10.8 & 0.8 & 0.05 & 0.52 & 0.04 \\
\hline Late maturity & 0 & 1.2 & 0.004 & 0.00 & 0.00 \\
\hline Disease tolerant & 5.8 & 0.8 & 0.03 & 0.19 & 0.03 \\
\hline Good taste & 11.2 & 8.6 & 0.06 & 0.68 & 0.52 \\
\hline High prices & 9.8 & 10.8 & 0.08 & 0.76 & 0.84 \\
\hline Market availability & 10.8 & 17.8 & 0.21 & 2.27 & 3.74 \\
\hline Seed availability & 0 & 9.6 & 0.03 & 0.00 & 0.29 \\
\hline Improvement of soil fertility & 50 & 20.5 & 0.06 & 3.2 & 1.31 \\
\hline Not attractive tobirds & - & 20.5 & 0.004 & - & 0.82 \\
\hline Total score & 163 & 139.4 & 1.00 & 26.40 & 17.97 \\
\hline
\end{tabular}

** = Integrated Lowland Rice Legume Technologies,. * = Conventional Practices.

\subsubsection{Likelihood of the Adoption of the Integrated Lowland Rice-Legume Technologies}

The results in Table 4 indicate that ILRLT have a maximum adoption rate of $37 \%$ by rainfed rice farmers and $52.7 \%$ of irrigated lowland rice farmers. This makes a total maximum adoption rate (MAR) of $89.7 \%$. 
Table 4. Maximum possible adoption rate of ILRLT

\begin{tabular}{lcc}
\hline Production goals & \multicolumn{2}{c}{ Frequency of farmer category (\%) } \\
\cline { 2 - 3 } & Rainfed & Irrigated \\
\hline Food security & 11.2 & 15.9 \\
Market ( Income) & 47.5 & 37.2 \\
MAR (\%) & 37 & 52.7 \\
\hline Overall MAR (\%) & & 89.7 \\
\hline
\end{tabular}

These results suggest that in situations of interaction between different production environments, goals and farmer categories; blanket recommendations have low maximum adoption rates. Therefore in order to increase the maximum adoption rates flexible recommendations that combine several-dimensions of the technology are needed.

Decision options to increase adoption for each production environment and category of farmers are therefore suggested.This can be achieved by presenting a brief description of each technology and what a farmer can expect from each, or by presenting 'if then' selection advise.Incorporating farmer's preferences criteria into ILRLT will increase adoption of the technology.

\section{Conclusion}

Integrated lowland Rice Legume Technologies fulfils most of the farmer's criteria than farmer's practices.

Based on farmers' category and production objectives model, Integrated Lowland Rice Legume Technologies are likely to be adopted bysmall holder farmers in Morogoro to the Maximum Adoption Rate (MAR) of 89.7\%. However, adoption rate is likely to be more for farmers who depend on irrigation than those depending on rainfed agriculture.

Adoption of Integrated Lowland Rice Legume technology is likely to increase and be sustainable with flexible recommendations that address farmer's criteria and production environments.

Adoption of agricultural technologies is likely to increase if factors for adoption are pre-ante identified and considered in development of the technologies.

Adoption of Integrated Lowland Rice Legume Techology will enhance sustainability of the lowland rice farming system by increasing food security and income to farmers due to its ability to improve soil fertility, effective utilization of water resources and utilization of the fallow land after rice.

\section{Acknowledgments}

Authors are grateful to the Association for Strengthening Agricultural Research in Eastern and Central Africa (ASARECA) for providing funds to carry out this study. Special thanks to the Coordinator and the Secretariat for ASARECA Staple Crops program for the support during this study. The input of extention staff and farmers in the study sites of Morogoro is highly acknowledged. Authors are also grateful to anonymous reviewers of this paper.

\section{References}

Bowerman, L., O'Connell, \& Murphree, R. E. (2011). Business Statistics in Practice (6th ed.). New York, MacGraw- Hill.

Bryman, A. (2012). Social Research Methods (4th ed.). Oxford University Press.

Bryman, A., \& Cramer, D. (1990). Quantitative Data Analysis for Social Scientists. London, Routledge.

Burns, R. B. (2000). Introduction to Research Methods (4th ed.). London, Sage Publications.

Cramb, R. A. (2003). Processes affecting the successful adoption of new technologies by smallholder.In Hacker, B (ed).Working with farmers: The key to adoption of forage technologies (pp. 12-15). ACIAR Proceedings No. 95. Canberra: Australian Centre for International Agricultural Research.

Das, A., \& Ghosh, P. K. (2012). Role of legumes in sustainable agriculture and food security: an Indian perspective. Outlook in Agriculture, 41(4), 279-284. http://dx.doi.org/10.5367/0a2012019

De Graaff, J., Amsalu, A., Bodner, F., Kessler, A., Posthumus, H., \& Tenge, A. J. (2008). Factors influencing adoption and continued use of long-term soil and water conservation measures in five developing countries. 
Applied Geography, 28, 271-280. http://dx.doi.org/10.1016/j.apgeog.2008.05.001

De Pauw, E. (1984). Soils, Physiography and Agro-Ecological Zones of Tanzania.Crop Monitoring and Early Warning Systems Project, FAO.GCPS/URT/047/NET, Ministry of Agriculture, Dar es Salaam.

Devore, J., \& Peck, R. (1993). Statistics: The Exploration and Analysis of Data. Duxbury Press, Califonia.

D’Souza, G., Cyphers, D., \& Phipps, T. (1993). Factors affecting the adoption sustainable agricultural Practices. Agricultural and Resources Economics Review, 159-165.

Field, A. (2005). Discovering Statistics using SPSS (2nd ed.). London, SAGE Publications.

Hella, J. P. (2004). Economic analysis of the relationship between smallholder farming strategies and soil degradation in semi-arid central Tanzania. PhD Thesis. Universiteit Gent.

Kashumba, F. (2010). Factors influencing choice of unemployment coping strategies among the rural youth in Tanzania: The case of Muleba district, Kagera region. MA. Dissertation, University of Dodoma, Tanzania.

Kinyau, M., Ley, G. J., Hella, J. P., Tenge, A. J., Opio, F., \& Rwomushana, I. (2013). Economic analysis of rice legume rotation systems in Morogoro,Tanzania. International Journal of Agricultural Policy and Research, 1(2), 41-47. Retrieved from http://www.Journalissue.org/journals/articles/1365135745

Kirway, \& Lema. (2003). Farming Systems Approaches Training Manual. MoAFS, Dar es Salaam.

Knowler, D., \& Bradshaw, B. (2007). Farmers' adoption of conservation agriculture: A review and synthesis of recent research. Food Policy, 32, 25-48. http://dx.doi.org/10.1016/j.foodpol.2006.01.003

Kothari, C. R. (2008). ResearchMethodology. Methods and Techniques (2nd.ed.). New Age International Publishers.

Ley, G. J., Baltissen, G., Veldkamp, W. J., Nyaki, A. S., \& Schrader, T. (2002). Towards Integrated Soil Fertility in Tanzania: Developing farmers' options and responsive policies in the context of prevailing agro-ecological, socio-economic and institutional conditions. Ministry of Agriculture and Food Security, Dar-es-Salaam, Tanzania and the Royal Tropical Institute (KIT), The Netherlands. KIT Publishers, pp 102.

Ley, G. J., Razakamiamana, Tenge, A. J., \& Ravoavison, G. (2012). Integrated Management Options for Sustainable Lowland rice-legumes Cropping System.Research Report for ASARECA. Entebbe. Retrieved January 22, 2013, from http://www.asareca.org

Maro, F. (2010). Social and economic factors that influence youth disengagement in agriculture in Morogoro, Tanzania. MA. Dissertation, University of Dodoma, Tanzania.

Meertens, H. (2003). The prospects for integrated nutrient management for sustainable rainfedlowland rice production in sukumaland, Tanzania. Nutrient Cycling in Agroecosystems, 65, 163-171. http://dx.doi.org/10.1023/A:1022103913683

Moore, D. (1993). Introduction to the Practices of Statistics. W.H. Freeman and Company. Purdue University, New York.

Norusis, M. J. (1990). Statistical Package for Social Sciences [SPSS]: Advanced Statistical Guide. SPSS International BV. Gronchem.

Perret, S. R., \& Steven, J. B. (2003). Analyzing the low adoption of water conservation technologies by smallholder farmers in Southern Africa. Extension and Rural Development University of Pretoria. Pretoria.

Semgalawe, Z. M., \& Folmer, H. (2000). Household Adoption Behaviorof Improved SoilConservation: the case of the North Pare and West Usambara Mountains of Tanzania. Land Use Policy Volume, 17(4), 321-336. http://dx.doi.org/10.1016/S0264-8377(00)00033-8

Sheikh, A. D., Mohamed, M. A., Bashir, A., \& Kashif, M. (2006). Adoption of rice technological package by farmers of irrigated Punjab. Journal of Agr. Res, 44(4), 341-353.

Stroup, W. W., Hildebrand, P. E., \& Francis, C. A. (1991). Farmer participation for more effective research in sustainable agriculture. Staff paper series SP91-2, September 1991. Food and Resource economics department.Institute of Food and Agricultural Sciences.University of Florida. Gainesville, Florida 32611.

Tenge, A. J. (2005). Participatory appraisal for farm level soil and water conservation planning in West Usambara highlands, Tanzania.Tropical Resource Management Paper.Wageningen University and Research Centre.Wageningen.

Tenge, A. J., De Graaff, J., \& Hella, J. P. (2004). Social and Economic Factors Affecting the Adoption of Soil 
and Water Conservation in West Usambara Highlands, Tanzania. Land Degradation and Development, 15, 99 -114. http://dx.doi.org/10.1002/ldr.606

Tenge, A. J., De Graaff, J., \& Hella, J. P. (2005). Financial efficiency of major soil and water conservation measures in West Usambara Highlands, Tanzania. Applied Geography, 25, 348-366. http://dx.doi.org/10.1016/j.apgeog.2005.08.003

Tenge, A. J., Stroosnidjer, L., \& De Graaff, J. (2009). The Use of Multi-Criteria Analysis for the appraisal of soil and water conservation measures in West Usambara highlands, Tanzania. Journal of Social Sciences, 1(1), 53-62. Retrieved November 12, 2013, from http://www.udom.ac.tz

United Republic of Tanzania (URT). (2008). Agricultural Maps. Ministry of Agriculture, Food Security and Cooperatives. Retrieved May 25, 2013, from http://www.agriculture.go.tz/agriculture

\section{Copyrights}

Copyright for this article is retained by the author(s), with first publication rights granted to the journal.

This is an open-access article distributed under the terms and conditions of the Creative Commons Attribution license (http://creativecommons.org/licenses/by/3.0/). 